\title{
The Potency of Anting Anting (Acalypha indica L.) Leaf Extract as An Acaricide on Boophilus microplus in Larvae and Adult Stages In Vitro
}

\author{
${ }^{1)}$ Fitri Nurdiana, ${ }^{2)}$ Rahmi Sugihartuti $\left.{ }^{(D)}, 3\right)$ Bambang Sektiari Lukiswanto \\ ${ }^{1)}$ Student, Faculty of Veterinary Medicine, Universitas Airlangga, fitri.nurdiana-2019@fkh.unair.ac.id \\ ${ }^{2)}$ Division of Veterinary Basic Medicine, Faculty of Veterinary Medicine, Universitas Airlangga \\ ${ }^{3)}$ Division of Veterinary Clinic, Faculty of Veterinary Medicine, Universitas Airlangga \\ Corresponding author: rahmi-s@fkh.unair.ac.id
}

\begin{abstract}
The purpose of this study was to determine the potency of anting-anting leaf extract (Acalypha indica L.) as an acaricide against larval and adult Boophilus microplus in vitro by observing the mortality rate of $B$. microplus. The present study design was a completely randomized design. This study used five treatments, including: Tween $801 \%$ and aquadest $(\mathrm{K}-)$, Neguvon $(\mathrm{K}+)$, anting-anting leaf extract with a concentration of $3.125 \%\left(\mathrm{P}_{1}\right), 6.25 \%\left(\mathrm{P}_{2}\right)$, and $12.5 \%\left(\mathrm{P}_{3}\right)$. Each treatment used 5 repetitions and each repetition used 6 B. microplus larval stages and $5 B$. microplus adults. Observations were made for 5 hours for the larval stage of B. microplus and 24 hours for the adult stage of B. microplus. Boophilus microplus is declared dead if there is no movement at all when touched with a needle. The data obtained were analyzed using factorial ANOVA and continued with Duncan's multiple distance test. The results showed that the $12.5 \%$ anting anting leaf extract treatment showed no significant difference with the treatment using Neguvon. (p>0.05) in larval stage B. microplus, but in adult $B$. microplus showed a significant difference with Neguvon $(\mathrm{p}<0.05)$. The results of the statistical test can be concluded that the extract of anting-anting leaf ( $A$. indica L.) has the potential as an acaricide of $B$. microplus larval stage in vitro. The higher the concentration of anting anting leaf extract, the higher the acaricide activity.
\end{abstract}

Keywords: Acalypha indica, Boophilus microplus, acaricide, leaf extract, in vitro, Adult stage.

\section{Introduction}

Boophilus microplus is an ectoparasite that often causes problems for cattle breeders in Indonesia. Boophilus microplus infestation causes various major losses such as: decreased body weight, decreased milk production, impaired comfort in livestock, and skin damage (Avinash et al., 2017). Boophilus microplus also acts as a vector for blood protozoan diseases such as: Anaplasmosis, Babesiosis, and Theileriosis (Soulsby, 1982). Health problems, especially those related to $B$. microplus, have not been completely addressed. Losses due to $B$. microplus infestation continue to increase from year to year (Adenubi et al., 2016). One of the methods used by cattle breeders to control cow ticks is to use chemical acaricides. Some examples of chemical acaricides include: Coumaphos (Asuntol), Propoksur, Cypermethrin and Pyrethroids (Husna, 2014). The use of chemical acaricides in livestock is not necessarily safe, given the presence of harmful chemicals in acaricides. The impacts due to the use of chemical acaricides include: causing poisoning or even death in livestock, killing nontarget organisms, and accumulation of acaricide residues in either meat or milk (Kumar et al., 2016). In addition, the uncontrolled use of chemical acaricides can lead to the emergence of resistant tick lines (Abbas et al., 2014). In connection with various problems and losses caused by $B$. microplus infestation, it is necessary to alternative acaricides as an effort to control cow ticks. One alternative that can be done is to use herbal plants that have the potential to control the population of cow ticks. The use of herbal acaricides has the advantage of being easy to obtain in nature and easy to decompose so that not to pollute the environment (Rohimatun and Wiratno, 2015). Plants that can be used as an alternative to acaricides are anting anting plants (Acalypha indica L.). The phytochemical content of anting anting leaves includes alkaloids, tannins, steroids, saponins, flavonoids, glycosides, acalyphin and phenol (Mohan et al., 2012). Previous study has shown that anting 
anting leaf extract can be used as an in vitro antiscabies (Astuti, 2019) and larvicide for Anopheles stephensi mosquitoes (Govindarajan et al., 2008). Based on the description above, it is necessary to conduct research to determine the acaricide potential of anting anting leaf extract against B. microplus with various concentrations.

\section{Materials and Methods}

The research design used in this study was a completely randomized design (CRD). Each treatment used five repetitions and each replication used 6 larval stage B.microplus and 5 adult stage B.microplus. The treatments consisted of: Tween $801 \%$ and aquadest (K-), Neguvon $(\mathrm{K}+)$, ethanol extract of anting anting leaves with a concentration of 3.125\% (P1), 6.25\% $\left(\mathrm{P}_{2}\right)$, and $12.5 \%\left(\mathrm{P}_{3}\right)$. Observations on the larval stage of $B$. microplus were carried out for 5 hours, while for the adult stage of $B$. microplus it was carried out for 24 hours. B. microplus larvae are declared dead if there is no reaction to movement when touched with a needle and generally the legs of the dead larvae look like they are rolled up (Wardhana et al, 2005). Adult $B$. microplus is declared dead if when touched there is no response to movement and the tick's cuticle looks dark (Fernández-Salas, 2011). The process of rearing adult female $B$. microplus that was full of blood was carried out in Pandantoyo Village, Ngancar District, Kediri Regency. Boophilus microplus adult females that have been filled with blood are placed in a container that has been lined with filter paper. During the rearing process the humidity is maintained by spraying water on the filter paper. The container is closed using a folded gauze. The container is placed in a box. The optimal environmental temperature and humidity for incubation of $B$. microplus eggs is $20^{\circ} \mathrm{C}-31^{\circ} \mathrm{C}$ with $70-90 \%$ humidity (Hitchcock, 1955). The larvae of $B$. microplus used in this study were 7 days old (Sindhu et al., 2012).

\section{Data Analysis}

The data obtained were analyzed by ANOVA $(\alpha=0.05)$, if there was a difference in the treatment data, it was continued with Duncan's double spaced test. The values of Lethal Concentration $50 \quad\left(\mathrm{LC}_{50}\right)$ and Lethal Concentration 9o (LC9o) were analyzed using probit analysis test. Statistical analysis was carried out using the SPSS for windows 23 program.

\section{Results and Discussion}

Table 1. Mean and Standard Deviation of Mortality of B.microplus Larvae Stadium Based on Interaction of Treatment and Time

\begin{tabular}{|c|c|c|c|c|c|}
\hline $\begin{array}{c}\text { Hour / } \\
\text { Treatment }\end{array}$ & $0-1$ & $1-2$ & $2-3$ & $3-4$ & $4-5$ \\
\hline K- & $0.00^{a} \pm 0.00$ & $0.00^{a} \pm 0.00$ & $0.00^{a} \pm 0.00$ & $0.00^{a} \pm 0,00$ & $0.40^{a} \pm 0.54$ \\
\hline $\mathrm{K}+$ & $1.40^{b} \pm 0.57$ & $2.80^{d} \pm 1.30$ & $6.00^{h} \pm 0.00$ & $6.00^{h} \pm 0,00$ & $6.00^{\mathrm{h}} \pm 0.00$ \\
\hline$P_{1}$ & $0.00^{a} \pm 0.00$ & $0.40^{\mathrm{a}} \pm 0.54$ & $1.00^{\mathrm{a}} \pm 0.00$ & $1.00^{\mathrm{bc}} \pm 0,54$ & $2.20^{\mathrm{cd}} \pm 0.83$ \\
\hline $\mathrm{P}_{2}$ & $0.00^{\mathrm{a}} \pm 0.00$ & $1.20^{\mathrm{b}} \pm 0.44$ & $2.00^{c} \pm 0.70$ & $3.20^{\mathrm{ef}} \pm 0,44$ & $3.80^{f} \pm 0.44$ \\
\hline $\mathrm{P}_{3}$ & $0.40^{a} \pm 0.40$ & $1.40^{\mathrm{b}} \pm 0.54$ & $3.00^{\mathrm{de}} \pm 0.70$ & $5.60^{\mathrm{gh}} \pm 0.54$ & $5.8 \mathrm{o}^{\mathrm{gh}} \pm 0.44$ \\
\hline
\end{tabular}

Note: Different superscripts show significant differences $(\mathrm{p}<0.05)$.

K- (Negative Control), K+ (Positive Control), P1 (Treatment 1), P2 (Treatment 2), P3 (Treatment 3)

Table 2. Mean and Standard Deviation of Mortality of B. microplus Adult Stage Based on Interaction of Treatment and Time

\begin{tabular}{|c|c|c|c|c|c|c|}
\hline $\begin{array}{c}\text { Hopur / } \\
\text { Treatment }\end{array}$ & $0-4$ & $4-8$ & $8-12$ & $12-16$ & $16-20$ & $20-24$ \\
\hline $\mathrm{K}-$ & $0.00^{\mathrm{a}} \pm 0.00$ & $0.00^{a} \pm 0.00$ & $0.00^{a} \pm 0.00$ & $0.00^{\mathrm{a}} \pm 0.0$ & $0.20^{\mathrm{a}} \pm 0.44$ & $0.40^{\mathrm{a}} \pm 0.5$ \\
\hline $\mathrm{K}+$ & $0.40^{a} \pm 0.54$ & $1.60^{b c} \pm 0.8$ & $2.6 \mathrm{o}^{\mathrm{a}} \pm 1.51$ & $3.40^{\mathrm{f}} \pm 1.1$ & $4.20^{\mathrm{gh}} \pm 0.8$ & $4.60^{h} \pm 0.5$ \\
\hline $\mathrm{P}_{1}$ & $0.00^{\mathrm{a}} \pm 0.00$ & $0.00^{a} \pm 0.00$ & $0.00^{\mathrm{a}} \pm 0.5$ & $0.40^{a} \pm 0.5$ & $0.40^{\mathrm{a}} \pm 0.44$ & $0.80^{\mathrm{a}} \pm 0.4$ \\
\hline $\mathrm{P}_{2}$ & $0.00^{\mathrm{a}} \pm 0.00$ & $0.20^{\mathrm{a}} \pm 0.44$ & $0.80^{a} \pm 0.44$ & $1.40^{b c} \pm 0.5$ & $1.80^{c d} \pm 0.83$ & $2.20^{\mathrm{d}} \pm 0.8$ \\
\hline$P_{3}$ & $0.00^{a} \pm 0.00$ & $0.60^{a} \pm 0.5$ & $1.20^{\mathrm{bc}} \pm 0.4$ & $2.20^{\mathrm{d}} \pm 0.4$ & $2.80^{\mathrm{e}} \pm 0.83$ & $3.60^{f} \pm 0.5$ \\
\hline
\end{tabular}


Based on probit analysis, it was shown that the $\mathrm{LC}_{50} \mathrm{O}$ of the ethanol extract of anting anting leaves against the larval stage of $B$. microplus was $4.05 \%$ and LC90 $12.2 \%$. This indicated that the low concentration of anting anting leaf ethanol extract was able to kill $B$. microplus larval stage in vitro. Probit analysis showed that the $\mathrm{LC}_{5} \mathrm{O}$ of the ethanol extract of anting anting leaves against the adult stage B. microplus was $6.8 \%$ and LC9o was $20.43 \%$. The results of the analysis showed that to kill the adult stage of B.microplus, a much higher concentration of ethanol extract of anting anting leaves was required. Research on the potential of anting anting leaf extract against various parasites has been carried out, namely: Anopheles stephensi mosquito (Govindarajan et al., 2008), Plasmodium falciparum (Brahmam and Sunita, 2018), and Sarcoptes scabiei (Astuti, 2019). The results of these studies showed different lethal concentration results. Research by Govindarajan et al (2008) showed that the concentration of benzene extract of anting anting leaves which was able to cause death by $50 \%$ in third instar larvae of Anopheles stephensi was $19.25 \mathrm{ppm}$. The concentration of anting-anting leaf methanol extract which was able to cause death of $50 \%$ in third instar larvae of Anopheles stephensi was $15.3 \mathrm{ppm}$. The concentration of anting-anting leaf chloroform extract which was able to cause the death of the third instar larvae of Anopheles stephensi showed the highest value of 27.76 ppm. The results of Astuti's research (2019) stated that the LC9o concentration of the ethanol extract of anting anting leaves for the Sarcoptes scabiei was $12.5 \%$. The results of Brahmam and Sunita's research (2018) showed that the chloroform extract of anting anting leaves was able to cause the death of $50 \%$ of Plasmodium falciparum at a dose of $1.47 \mathrm{~g} / \mathrm{mL}$. The concentration of ethyl acetate extract of anting anting leaves was able to cause $50 \%$ death of Plasmodium falciparum at a dose of $2.32 \mathrm{~g} / \mathrm{mL}$, while methanol extract required a larger dose to cause death of $50 \%$ in Plasmodium falciparum, which was $23.91 \mathrm{~g} / \mathrm{mL}$. The results of several studies can be concluded that anting anting leaf extract can be used as an antiparasitic with different doses depending on the type of parasite and the solvent used. Saponin compounds have soap-like properties and can damage the cuticle layer that protects the body of the B. microplus (Chaieb, 2010). The cuticle damage of ticks can facilitate the penetration of phytochemical compounds in other anting anting leaf extracts. Saponins are able to reduce the surface tension of the mucous membranes of the digestive system so that the walls become corrosive and damaged (Dinata, 2008). As a result, the work of digestive enzymes and food absorption in adult B. microplus can decrease. This mechanism can cause $B$. microplus to die because they are unable to digest food, starve and then become weak and die. Saponin compounds are also able to bind sterols in the digestive tract so that there is a decrease in the rate of sterols in the hemolymph (Muta'ali and Purwani, 2015). Sterols are precursors of the hormone ecdysone for the $B$. microplus. The decrease in sterol supply will greatly affect the ecdysone hormone in $B$. microplus. Ecdysone hormone is useful in the process of skin turnover in $B$. microplus to be able to grow to the next stage (Chaieb, 2010). The ecdysone hormone in adult female $B$. microplus also regulates the process of oogenesis and oviposition (Rees, 2004). This mechanism can cause $B$. microplus to die because they fail to metamorphose and oogenesis disturbances occur. The content of flavonoid compounds works by inhibiting acetylcholinesterase. As a result, acetylcholine cannot be broken down into choline and acetate. Inhibition of this enzyme can lead to accumulation of acetylcholine at the synapse. Accumulation of acetylcholine causes continuous stimulation of post synaptic receptors. The mechanism of action of flavonoids in the adult stage of $B$. microplus is less clear when compared to the larval stage of B. microplus. This mechanism indicates that the content of flavonoid compounds can act as neurotoxins in $B$. microplus.

\section{Conclusion}

Anting anting leaf ethanol extract has potential as an acaricide against larval stage $B$. microplus and less potential as an acaricide in adult stage $B$. microplus.

\section{References}

Abbas, R.Z., Zaman M.A., Colwell, D.D., Gilleard J., Iqbal, Z. 2014. Acaricide Resistance in Cattle Ticks and Approaches to its Management : The State of Play. J. Vet Parasitology: 6-20.

Adenubi, O.T, Fasina, F.O., McGaw, L.J., Eloff, J.N., Naidoo, V. 2016. Plant Extracts to Control Ticks of Veterinary and Medical Importance. South African J.of Bot: 178-193. 
Astuti, L. T. 2019. Potensi Ekstrak Daun Antinganting (Acalypha indica L.) sebagai AntiSkabies terhadap Sarcoptes scabiei var. cuniculi secarain-vitro [Skripsi]. Fakultas Kedokteran Hewan, Universitas Airlangga.

Avinash, B.,Venu, R., Alpha, R.M., Srinivasa, R.K., Srilatha, C., and Prasad, T.N. 2017. In-vitro valuation of Acaricidal Activity of Novel Green Silver Nanoparticles Against Deltamethrin Resistance Rhipicephalus (Boophilus) microplus. J.Vet.Parasitol.1-24.

Brahmam, P. dan Sunita, K. 2018. Phytochemical Investigation and In vitro

Antimalarial Activity of Acalypha indica L. and Cocculus hirsutus L. from Prakasam District, Andhra Pradesh, India. J.Biomed and Pharmacol. 2123-2134.

Chaieb, I. 2010. Saponin As Insecticide: A Review. Tunisian J. of Plant Protect.5: 39-50.

Dinata, A. 2008. Pemberantasan Penyakit Bersumber Binatang. http://www.litbang.depkes.go.id/lokaciami s/artikel/nyamuk-arda.htm. [20 Desember 2019]

Govindarajan, M., A. Jebanesan, T. Pushpanathan, dan K. Samidurai. 2008. Studies on the effect of Acalypha indica (Euphorbiaceae) leaf extracts on the malarial vector Anopheles stephensi Liston (Diptera: Culicidae). J. Parasitol. 691-695.

Hitchcock, L.F. 1955. Studies on the parasite stage of the cattle tick. Boophilus microplus (Canestrin)(Acarina, Ixodidae) Aust. J. Zoo. 3: 145-155.

Husna, S. 2014. Efektifitas Insektisida terhadap Larva Caplak (Boophilus microplus) Peternakan Sapi Potong di Jonggol Kabupaten Bogor [Skripsi]. Fakultas Kedokteran Hewan. Institut Pertanian Bogor.
Kumar, A.K., Sharma, A.K., Kumar, S., Ray, D.D., Rawat, A.K., Srivastava, S., dan Ghosh, S. 2016. Comparative In-vitro Anti Tick Efficacy of Commercially Available Products and Newly Developed PhytoFormulation Againts Field Collected and Resistant Tick Lines of Rhipicephalus (Boophilus) microplus. J. Parasit. Dis. 40 : 1590-1596. Play. J. Vet Parasitology: 6-20.

Mohan, C.S., S. Dinakar, T. Anand, Elayaraja R., Sathiyapriya B. 2012. Phytochemical, GCMS Analysis and Antibacterial activity of a Medicinal Plant Acalypha indica. Int. J. of PharmTech Res.1050-1054.

Muta'ali, R. dan Purwani, K. I. 2015. Pengaruh Ekstrak Daun Beluntas ( Pluchea indica) terhadap Mortalitas dan Perkembangan Larva Spodotera litura F. Jurnal Sains dan Seni ITS.4: 55-58.

Ress, H.H. 2004. Hormonal Control of Tick Development and Reproduction. J. Parasitol. 129(1):127-143.

Sindhu, Z., Jonsson N., Iqbal Z. 2012. Syringe test (Modified Larval Immersion Test): A New Bioassay for Testing Acaricidal Activity of Plant Extracts Againts Rhipicephalus microplus .J. Vet. Parasitol.188: 362-367.

Soulsby, E. J. 1982. Helminth, Arthropods and Protozoa of DomesticatedAnimals. London: $7^{\text {th }}$ (hlm 462) Ed Billiere, Tindall \& Cassel Ltd.

Wardhana, A.H., Amir Husein dan J. Manurung. 2005. Efektifitas Ekstrak Biji Srikaya (Annona squamosa L) dengan Pelarut Air, Metanol, dan Heksan terhadap Mortalitas Larva Caplak Boophilus microplus secara Invitro. JITV.10 (2) :134-142 